\title{
Хронология и идеология \\ (За начало на славянската писменост \\ според учебниците \\ по история и кирилометодиевистиката)
}

\author{
Диана АТАНАСовА, Бойко ПенчЕВ \\ Софийски университет „Св. Климент Охридски” \\ adiana@slav.uni-sofia.bg \\ Софийски университет „Св. Климент Охридски” \\ boyko@slav.uni-sofia.bg
}

Recibido: Mayo de 2013

Aceptado: Diciembre de 2013

\begin{abstract}
Резюме
Статията разкрива идеологическите основания и импликации зад научния дебат около годината на създаване на славянската азбука от светите братя Кирил и Методий. Въпреки всички исторически и филологически аргументи, в учебниците по история и справочните издания все още стои годината 855 (а не 863 или 862). Статията проследява връзката между посочването именно на 855 г. и идеологическите разкази, полагащи българските славяни като главна цел на културната и мисионерска дейност на светите братя.
\end{abstract}

Ключови думи: Кирил и Методий, създаване на славянската писменост, славистика

Cronología e ideología (Sobre el principio de la escritura eslava según los libros de Historia y de Cirilometodievística)

\section{Resumen}

El artículo presenta las bases y las implicaciones ideológicas que se esconden tras el debate científico sobre el año de la creación del alfabeto eslavo por los Santos hermanos Cirilo y Metodio. A pesar de todos los indicios históricos y filológicos en los libros de historia todavía se señala el año 855 y no el 863 o 862 como sería lo esperable. El artículo estudia la relación entre sostener el año 855 y los relatos ideológicos que señalan a los eslavos búlgaros como destinatarios principales de la actividad misionera de los santos hermanos.

Palabras clave: Cirilo y Metodio, creación de la escritura eslava, eslavística

Chronology and Ideology (On the Origin of Slavonic Writings according to the History Textbooks and the Cyrillo-Methodian Studies)

\begin{abstract}
The paper uncovers the ideological implications and underpinnings behind the scholarly debates about the exact year of the invention of the Slavonic writing by Sts. Cyril and Methodius. Despite the philological arguments, the year 855 stands firmly in the Bulgarian history textbooks from the 1950s up to nowadays, probably because it suits better the implicit narrative about the Bulgarian Slavs as a primary target of the religious and cultural mission of Sts. Cyril and Methodius.
\end{abstract}

Key words: Cyril and Methodius, invention of Slavonic writing, Slavic studies 
Целта на настоящия текст е да проследи генеалогията на един от многото фактоиди, с които са пълни българските учебници по история. Фактоидът е нещо, което се приема за факт, а всъщност не е. И не просто се приема за вярно, а се изисква като знание, което трябва да бъде усвоено от учениците и възпроизведено правилно по време на изпит. В случая става въпрос за точната година, в която е създадена славянската писменост от светите братя Кирил и Методий.

Годината, посочвана като сигурна и съответно задължителна за научаване във всички учебници за 5 и 11 клас, с които се запознахме при изследването1, е 855 г. Тя фигурира в десетки изпитни тестове и съответно носи (или не носи) точки на проверявания ученик. „Правилният” отговор ще намерим и в статията за св. Кирил в българската „Уикипедия” (но не и в руската, където годината е 863 !). Същата 855 г. се открива и в двете исторически съчинения с най-голяма популярност сред българската възрастна публика за последните 20 години „Български хроники” на Стефан Цанев (ЦАНЕВ 2006) и „12 мита в българската история" на Божидар Димитров (ДИМИТРОВ 2005).

Второто, което е съвсем сигурно, е, че българската азбука и преводите са създадени в 855 г. Годината е потвърдена не само от гръцки, но и от авторитетни български източници, като Черноризец Храбър. Ужасно важно сведение и ужасно точна дата - за нея няма никакво съмнение при всички историци. (ДИМИТРОВ 2005: 93)

Разбира се, Божидар Димитров малко е преувеличил. Съвсем сигурно е само, че няма нито гръцки, нито други източници, посочващи точна година, освен Черноризец Храбър в съчинението му „За буквите”, където се казва:

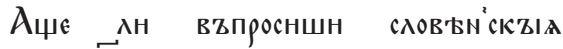
БОУКАРА ГАА. КТО вZI ПНСмена створНАZ

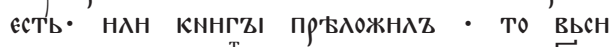

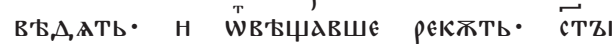
КWNстANTHNZ фнаософZ нарнцаєМZIH КнрН-

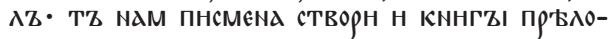

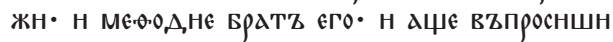

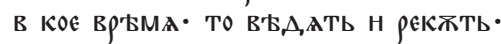

Ако ли попиташ славянски грамотни [хора], казвайки: „Кой ви е създал буквите или превел Книгите”, то всички знаят и отговаряйки, ще рекат: „Св. Константин Философ, наричан Кирил, той ни създаде буквите и преведе Книгите, и Методий, неговият брат. Още са живи онези, които са ги видели. И, ако попиташ в кое време, то знаят и ще рекат:

\footnotetext{
1 ПЕТЬР АНГЕЛОВ, ЦВЕТАНА ГЕОРГИЕВА, МАРИЯ РАДЕВА Учебник по история и изивилизация за 5 клас, ИК „Прозорец”, София, 2006; РАЙНА ГАВРИЛОВ, РУМЯНА КУШЕВА Учебник по история и ичвилизация за 5 клас, Издателство „Просвета”, София, 2006; ПЕТЪР ДЕЛЕВ, ГЕОРГИ БАКАЛОВ, ПЕТЬР АНГЕЛОВ История на България от древността до наши дни. Учебник за 11 клас, Издателство „Планета3”, 2001; ВАСИЛ ГЮЗЕЛЕВ, РАЙНА ГАВРИЛОВА Учебник по история и ичвилизация за 11 клас. Задължителна подготовка, Издателство „Просвета”, София, 2001; АЛЕКСАНДЪР НИКОЛОВ, МИТКО ДЕЛЕВ История и иивилизация за 11 клас. Профилирана подготовка, Издателство „Просвета”, София, 2001; ПЕТЬР ДЕЛЕВ, ПЕТЬР АНГЕЛОВ, ГЕОРГИ БАКАЛОВ История на България за 11 клас, Отворено общество, София, 1996. ГЕОРГИ БАКАЛОВ, ПЕТЪР АНГЕЛОВ История на България за гимназиалната степен на общообразователните и професионалните училища, Издателство „Булвест 2000”, София, 1993.
} 


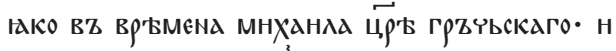

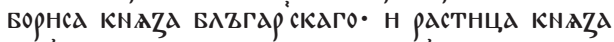

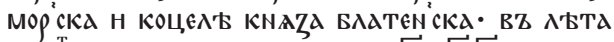

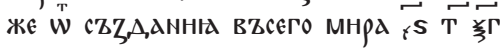

(Лаврентиев сборник от 1348 г., л. 105r) ${ }^{2}$
„По времето на Михаил, гръцкия цар, и на българския княз Борис, и моравския княз Растица, и блатненския княз Коцел в годината от сьтворението на целия свят шест хиляди триста шестдесет и трета".

(превод: Климентина Иванова) $)^{3}$

При подобни случаи обикновено се приема, че е използвано т. нар. „византийско летоброене", а за преминаване към познатата ни система за летоброене се използва индекс със стойност 5508. Т.е. от 6363 се изважда 5508 и се получава годината 855. В древността обаче е имало и други системи за летоброене, една от които е Александрийската, при която времето от сътворението на света до Въплъщението се приема за 5500 години и съответно е необходим друг индекс. Хипотезата, допускаща, че Храбър е използвал Александрийско летоброене, тръгва от хърватския славист Рачки (1859 г.), възприета е от редица руски учени от началото на XX в., като Лавров, Сперански, Соболевски, а неин български привърженик е Куйо Куев, който в множество публикации от началото на 60-те години, кулминиращи в книгата му „Черноризец Храбър” (КУЕВ 1967), доказва, че годината, посочена от Черноризец Храбър, е всъщност 863 (6363 минус 5500). В общи линии това е годината, която се приема от съвременната кирилометодиевистика ${ }^{4}$.

През 1977 г. обаче Иван Добрев в ключовата си студия „За александрийското и моравско-панонското летоброене и за някои дати в старата славянска писменост” (ДОБРЕВ 1977) категорично доказва, че Куев, заедно с учените преди него, грешат в пресмятанията си. В Александрийската система годините от началото на света до въпльщението на Христос са 5500, но това не означава, че Христос се е родил в първата година от новата ера. Спестявайки всички астрономически и календарни аргументи, достатьчно е да кажем, че Александрийската система изисква да се вади не 5500, а 5492. Тогава като година на създаването на славянската писменост се получава 871, което е абсурдно, защото св. Кирил умира още през 869 г. На свой ред Иван Добрев развива хипотезата, че в съчинението на Черноризец Храбър е използвана много специална система за летоброене, нито Александрийска, нито Византийска, която той нарича Моравско-Панонска. При нея, за да получим годината по нашето летоброене, трябва да извадим 5501 - което дава 862 г. Подробно и убедително аргументираната студия на Добрев обаче остава на практика незабелязана от официалната историография, която така или иначе приема за неоспорима годината 855.

2 В Лаврентиевия сборник от XIV в. се съдържа най-ранният препис на Храбровата творба. Вж. КУЕВ 1967: 188.

3 Вж. ИВАНОВА 1995: 99.

4 Вж. и обзорната статия на ЛАЛЕВА 1985 
Защо обаче въобще се търси друга система на летоброене, която да „коригира” получената по „нормалния” начин, т.е. чрез Византийското летоброене, 855 година?

Отговорът за старобългаристиката е ясен. Ако тълкуваме посочената от Храбър година като 855, то тогава тя не се сьгласува с важното указание, че това е станало „по времето на Михаил, гръикия цุар, и на българския княз Борис, и моравския княз Растииа, и блатненския княз Коцел" - тъй като блатненският княз Коцел е коронясан чак през 861 г.

Разминаването между „посочената” от Храбър година и историческите реалии е забелязано още през XIX в., ще го намерим у Осип Бодянски в неговия обзорен труд от 1855 г. „За времето на създаването на славянската писменост” (БОДЯНСКИ 1855). През годините филолози и историци по различен начин разрешават този проблем, избирайки между двете възможни години - 855 и 863 , като изборьт им се оказва зависим не само от наличните исторически данни и логиката, но и от предпочитанията към една или друга идеологическа концепция.

Още със зараждането на интереса към славянската древност, който възниква първо сред католическите църковни историографи от XVI-XVIII в. като Цезар Бароний, неговия коментатор Пагиус и Йосиф Асемани, се появява и въпросът за времето на възникването на славянската писменост. Годината 863 за пръв път е посочена от Пагиус. Тя е възприета и от бащите на славистиката Аугуст Шльоцер и Йозеф Добровски. Когато обаче през 1824 г. Константин Калайдович публикува като едно от приложенията на своята книга „Йоан, Екзарх Български” съчинението на Храбър „За буквите”, нещата се променят. Именно тогава започва „кариерата” на 855 г. Най-авторитетната фигура в славистиката по това време - Павел Шафарик - не само приема годината 855, но и в книгата си „Славянските старини” от 1837 г. предлага една класическа формулировка, обвързваща създаването на писмеността и дейността на светите братя сред българските славяни преди Моравската мисия:

Като знаел добре колко полезно е да се използва родният език в религиозните дела (...) Константин решил да направи участници в това благодеяние и самите славяни. С тази цел той създал през 855 г. славянската азбука, най-съвършената по рода си, в основата на която положил гръцкото писмо (...). Не само гръцките и българските славяни приели с радост предложения им дар, но даже самите уралски българи, по това време вече славянизирани в Мизия, се смекчили от силата на божието слово и Методий лично покръстил българския княз Борис през 861 г. Така че славянското богослужение започнало да се разпространява в периода 855 - 862 г. първо между гръцките, а след това и между българските славяни, граничещи (...) с моравската държава на знаменития Ростислав. (ШАФАРИК 1847: 316-317)5.

В периода между 1824 г. и 1840 г. господства авторитетьт на Шафарик и на Храбър. През 1843 г. обаче Александър Василиевич Горски публикува в сп. „Москвитянин” статия, в която коментира и преразказва Пространното житие на св. Константин-Кирил Философ (нататък ЖК) и Пространното житие на св. Методий (нататьк ЖМ) - прочутите „Панонски легенди”. Това дава началото

\footnotetext{
5 Цитатът е по руския превод от 1847 г., но оригиналното издание е от 1837 г. Преводите от руски са наши.
} 
на радикален обрат в тогавашната кирилометодиевистика. ЖК ясно обвързва създаването на славянската писменост с Моравската мисия на светите братя и общо-взето елиминира „българската връзка” в цялата история. Година не се посочва, но на базата на казаното и знанията кога идват пратениците на Ростислав и кога Кирил и Методий заминават за Великоморавия, се прави изводът, че азбуката и първите преводи са създадени през 862-863 г. И двата текста косвено указват годината 863 , но вече с авторитета на най-стар и подробен източник за дейността на светите братя.

Новата постановка на въпроса веднага се проявява в няколко историографски текста - трудовете на Архимандрит Макарий Булгаков (МАКАРИЙ 1846) и на харковския владика Филарет (ФИЛАРЕТ 1846)6. При Макарий имаме едно интересно обвързване - в една и съща година - 862 - е създадена славянската писменост и е основана руската държава (Киевска Рус). Това многозначително съвпадение ще бъде вдъхновено доразвито от Бодянски, който в средата на 50те години на XIX в. в своята монография „За времето на произхода на славянските писмена" (БОДЯНСКИ 1855), посветена специално на годината на създаването на славянската писменост, правейки пълен обзор на изворите и мненията по въпроса до момента, обвързва непоколебимо годината на създаването на писмеността (у Бодянски тя е 862 г.) и основния извор - ЖК.

Проблемът с ЖК обаче е, че то е твърде неудобно в идеологическо отношение. То поставя изобретяването на азбуката в пряка връзка с „поръчката” от страна на Ростислав. Тъй като е казано, че моравските славяни са били вече покръстени (само че са си нямали писменост на своя език), а за „българска връзка" няма и дума, апостолската роля на Кирил и Методий е някак туширана. Новият обрат настъпва през 1858 г., когато руският филолог и етнограф Александър Гилфердинг публикува Краткото житие на Кирил, т. нар. Успение Кирилово (нататьк УК) ${ }^{7}$. Това поставя началото на хипотезата за т.нар. „Брегалнишка мисия” - т.е. за просветителско-кръстителска дейност на светите братя в българските земи преди Моравската мисия. Всъщност УК се различава съществено от ЖК в един епизод, който обаче е ключов.

След това отиде на река Брегалница и там намери няколко от славянското племе покръстени. А които пък намери непокръстени, той ги покръсти и ги обърна в православната вяра. И създаде им букви на славянски език. Тези, които обърна в християнската вяра, бяха 54 000. (ДИНЕКОВ 1967: 140) 8

\footnotetext{
6 Според Филарет Методий, по пътя си към Моравия, покръства Борис (ФИЛАРЕТ 1846: 3, цитирано по БОДЯНСКИ 1855: 205).

7 Малко по-късно на базата на УК Василий Билбасов в своя критичен обзор върху изворите за КирилоМетодиевото дело заявява, че УК е първостепенен източник за дейността на братята, че е по-ранно от ЖК (БИЛБАСОВ 1871: 61). Тезата, че УК е по-ранно от ЖК може да се смята за категорично отхвърлена, но в средата на XX в. тече спор колко ранно/късно е то. Според Емил Георгиев, големият радетел на Брегалнишката мисия, УК е написано много рано, още в кръга ученици на Методий и Климент, т. е. началото на Х в. (вж. например ГЕОРГИЕВ 1980: 13-20). Към момента мнението на науката е, че става дума за паметник от XIII в. (ИВАНОВА 1999, ЧЕШМЕДЖИЕВ 2001). Нещо повече, самото „българизиране” на Кирил и Методий в текстове като УК става обект на изследване като свидетелство за промяната в историческото съзнание и появата на определен тип владетелска идеология. (ЧЕШМЕДЖИЕВ 2001: 86-91)

${ }^{8}$ В бележка към пасажа за Брегалница се казва „Нека се помни, че през Борисово време тези краища са в български ръце. Неприемливо е да се сметне, че Борис ще допусне тук византийски мисионери да разпространяват християнството, когато той още не е покръстил българския народ” (ДИНЕКОВ 1967: 140).
} 
Гилфердинг игнорира ЖК и ЖМ, изказвайки теза, която ще стане любима на комунистическите и националистически български историци от втората половина на XX в. - а именно, че двете жития са писани, за да се харесат на великоморавските владетели и затова премълчават дейността на братята сред българите. Според изследователя най-ранният документ е всъщност „Успение Кирилово". Въз основа на сведенията от УК и посочената от Храбър година, изтълкувана като 855 , той предлага един идеологически разказ, в който българските славяни (отново) се оказват първият адресат на просветителската и мисионерска дейност на светите братя.

Вече споменах за Сказанието на Храбър, където създаването на писмената е отнесено към 855 г. Освен това, има и други свидетелства, че създаването е извършено в Македония, че там Кирил е предприел превода на свещеното писание, за просвещението на славяните в своята родина, вече частично покръстени; указано е дори мястото, където Кирил е поставил началото на това дело, а именно Брегалница, област в Македония, където тече река, носеща и до днес това име. (ГИЛФЕРДИНГ 1862: 302)

Към аргумента от Храбър Гилфердинг добавя един важен „психологически” довод, съзвучен с романтическата представа за твореца, валидна по това време:

Ако Кирил не е бил завладян от убеждението в призванието си да стане просветител на народа славянски, ако тази идея не е расла в него заедно с него самия и не е била целта на живота му, а само случаен епизод в него, то би ли могло, за краткия си живот да извърши такова грамадно дело - дело, от което води началото си духовното развитие на славянските народи? (ГИЛФЕРДИНГ 1862: 301).

Така УК се превръща в опора на алтернативен исторически канон, акцентиращ върху дейността на братята сред българите.

Създаването на азбуката не е единственото звено, свързващо българите и Кирил и Методий. Изключително важно място в ранните исторически разкази заема покръстването на Борис от Методий. Това сведение се открива още у католическите историографи, а след това при Шафарик, Филарет и Гилфердинг. Ще го намерим и у Паисий. Този разказ добре се връзва с годината 855 , защото пък до средата на XIX в., под влияние на Пагиус, се смята, че Борис е покрьстен през 861 г. Ето и авторитетната теза на Шафарик от прочутия му труд „Славянските старини”:

... Като знаел добре колко полезно е да се използва родният език в религиозните дела (...) Константин решил да направи участници в това благодеяние и самите славяни. С тази цел той създал през 855 г. славянската азбука, най-съвършената по рода си, в основата на която положил гръцкото писмо (...) и след това пристьпил без отлагане към превода на светото Евангелие, Посланията, Псалтира и някои други книги, най-необходими за богослужението. Не само гръцките и българските славяни приели с радост предложения им дар, но даже самите уралски българи, по това време вече славянизирани в Мизия, се смекчили от силата на божието слово и Методий лично покръстил българския княз Борис през 861 г. Така че славянското богослужение започнало да се разпространява в периода 855 - 862 г. пьрво между гръцките, а след това и между българските славяни, граничещи (...) с моравската държава на знаменития Ростислав (ШАФАРИК 1847: 316-317)9

\footnotetext{
${ }^{9}$ Цитатът е по руския превод от 1847 г., но оригиналното издание е от 1837 г.
} 
Докато е валидно мнението, че покръстването на Борис е станало през 861 г., дори и привържениците на 862/3 като година на създаване на славянската писменост не отписват „българската връзка” в делата на светите братя. Покъсно обаче с появата на нови извори покръстването на Борис бива отнесено към по-късна година - 864 или 865 г., което вече прави трудно възможно както кръщаването му от Методий, така и разпространяването на славянска писменост и богослужение в Българските земи преди Моравската мисия (при положение, че България още не е покръстена).

Като цяло в периода от края на XIX и началото на XX в. доминира придържането към ЖК и 862 г. (,партията” на Бодянски). Споделят я авторитети като Ватрослав Ягич (който е скептичен към достоверността на Брегалнишката мисия), Марин Дринов (ДРИНОВ 1869), Васил Златарски (ЗЛАТАРСКИ 1971).

Идва обаче Девети септември и революцията се прехвърля и в историческата наука. Всьщност, можехме да започнем и оттам. Днешната 855 г. в учебниците по история е пряк наследник на „реформата” в историографията по времето на Вълко Червенков. През 1951 г. Александър Бурмов публикува в сп. „Исторически преглед” статията „За началото на славянската писменост и книжнина". Той започва с цитат от пространните жития на Кирил и на Методий, за да изтъкне колко вредно е тези свидетелства да бъдат следвани безкритично.

Облягайки се изключително на тези сведения, давайки им пълна вяра, без съответната историческа научна критика буржоазната историография достигна неминуемо до извода, че наистина Кирил и Методи са създали славянската писменост и книжнина по поръка на византийския император и че те са заминали за Великоморавия и са действували там като византийски мисионери, като агенти на политическите и религиозни цели на цариградското правителство. От този извод следва неминуемо друг един: създаването на славянската писменост и книжнина са нещо случайно, рожба на случайни обстоятелства, те са нещо случайно в дейността на Кирил и Методи. Ясно е от пръв поглед, че тези два извода са и антинаучни, и крайно тенденциозни. (БУРМОВ 1951-52: 52-53).

Патосът на Бурмов е съзвучен с предприетия в българската историческа наука в края на 40-те курс към освобождаване от „филологическия формализъм”. Тезата за 855 г. като година на създаването на славянската писменост ще залегне в двутомната „История на България” от 1954 г., след това в тритомната „История на България” от 1961 (автор на съответната статия и в двете е Ал. Бурмов), след това в том 2 от многотомната „История на България” (1981 г.), в „Кратка история на България” (1981), в тритомната „История на България” (1999) - в последните три авторитетни издания съответният раздел е написан от Васил Гюзелев. Междувременно в българската кирилометодиевистика въпросът за годината изглежда решен още през 1963 г., за което говори юбилейната конференция и издаденият след това том „Хиляда и сто години славянска писменост, 863-1963”, София, 1963. Оказва се обаче, че 855 е идеологически далеч по-сполучлива и мнението на кирилометодиевистиката остава „невидимо" за историческата наука и образователните институции.

Казано накратко, годината 855 е рудимент от разказ, който е включвал покръстването на Борис от Методий и просветителско-мисионерската дейност на светите братя в българските земи преди Моравската мисия. Това е разказът, 
който полага българските славяни, България и Борис като първи адресати на новосъздадената писменост. С течение на времето двата ключови елемента покръстването на Борис от Методий и Брегалнишката мисия - отпадат като легендарни от „сериозната” история, съответно няма да ги открием и в учебниците. Годината обаче остава. Извадена от своя смислов контекст, от идеологическата си съгласуваност, тя стои непонятно. Тъкмо липсващата логика провокира историци като Б. Димитров да се опитат да върнат обратно отпадналите елементи от разказа. В „12 мита в българската история” Божидар Димитров тръгва отзад напред - приемайки реторично 855 г. като „безусловна”, той задава основателния выпрос „за кого ще са я правили братята тази азбука” (след като не може да е поръчана от византийския император осем години преди пристигането на Ростиславовите пратеници, не може и да е заради осъзната апостолическа мисия, тъй като според Димитров южните славяни по това време са били вече покръстени). Впрочем в разказа на Александър Бурмов, един от категоричните поддръжници на 855 г., също липсват Брегалнишката мисия и покръстването на Борис (Бурмов смята, че християнизация в България преди 864 г. не е имало, а покръстването на българите е силово и внезапно наложено „отгоре” от Борис и феодалната аристокрация). При Бурмов обаче Кирил и Методий не е необходимо да създават буквите за когото и да било - те просто отговарят на „историческата нужда”, явяват се „изразители на историческата необходимост" (БУРМОВ 1951-52: 55). За Божидар Димитров марксисткият детерминизъм е вече чужд и той стига до единствено възможния логичен отговор - щом става дума за 855 г., има един-единствен владетел, който има стратегически интерес от създаването на славянска писменост, която ще пази идентичността на неговите славянски поданици. Това е Борис I, който тайно, още в първата половина на 850-те е порьчал азбуката на светите братя, а те съответно са работели като негови агенти под прикритие. Така отново се отваря място и за Брегалнишката мисия.

Брегалнишката мисия се е състояла между 855-864 г. и е била експеримент, целящ проверка на годността на азбуката и преводите, както бихме казали днес, „на терена за действие". Експеримент, наблюдаван лично от Борис I. (ДИМИТРОВ 2005: 97)

Всъщност Божидар Димитров просто реконструира и пуска в повторно обръщение един устойчив разказ, имащ своите корени още във Възраждането, и от който като безусловна истина е останала само годината, макар че тя, както видяхме, далеч не е безусловна.

Ако се върнем в зората на българската историография, ще открием още един Бурмов, ангажиран с въпроса за началото на славянската писменост само че не Александър, а Тодор. Тодор Бурмов, редактор на „Български книжици”, консерватор и бъдещ министьр-председател на Княжество България, през 1859-60 година публикува в сп. „Български книжици” дълга статия, озаглавена „За началото, разпространението и утвърждаването на християнската вяра между българите". Той е твърдо убеден, че светите братя са били в България, участвали са в покръстването на Борис, а са създали азбуката през 855 г. Твърденията на Шльоцер (бащата на модерната руска историография), че Методий не е онзи Методий, който е покръстил Борис според византийските 
хроники, Тодор Бурмов окачествява като нямащи „никаква важност”, а за Бодянски, който не приема годината 855 , казва, че „възраженията му против истинността на това показание (Храбровото) не са силни". На Тодор Бурмов силно му се иска да вярва, че „пребиваването на Кирила и Методия в България преди отхождането им в Моравия е несомнено" (БУРМОВ 1859-60: 578-579). Всъщност Тодор Бурмов просто артикулира с „учени” аргументи широко разпространеното през Възраждането вярване, че Методий е покръстил Борис намираме го отразено и в множество иконописни и живописни изображения, и в пиесата на Добри Войников „Покръстването на Преславския двор”. За дискурса на националната идеология е от ключово значение основополагащо събитие като покръстването на българите да бъде обвързано с престижна фигура като тази на св. Методий. Представата за светите братя като лично ангажирани с българите тръгва от книгата на Юрий Венелин „Критически издирвания за българската история", 1849, преведена от Ботьо Петков през 1853 г. Според Венелин Методий пряко участва в покръстването на Борис, а след това с брат си Константин и други духовници (със славянски произход) създават в двора на Борис азбуката и превеждат цялата необходима за богослужението книжнина на български език. Впрочем покръстването на Борис от Методий се е оказало също толкова „несомнено” и за Димитьр Маринов, който в своята „История на българската литература" от 1887 г. заявява, че Борис е повикал Кирил и Методий след покръстването (мислено като случило се през 861 г.) и те са дошли, донасяйки създадената на Олимп писменост.

И така, годината 855 се е оказала достатьчно гъвкава, за да подхранва различните идеологически разкази от средата на XIX в. до наши дни. Нейната устойчивост в историографския дискурс може би се дължи на това, че тя кодирано „помни” разказа, наследен всъщност от Паисий. В главата „За славянските учители” от „История Славянобългарская” ще намерим и трите ключови елемента - покръстването на Борис от Методий (макар че Паисий, който следва Мавро Орбини, бърка Борис с Мортагон), отиването на Кирил и Методий да „учат българите (първо) и останалите славяни на християнска вяра” и съставянето на буквите. При Паисий не е много ясно кое след кое следва, няма и посочени години. Историците обаче след него, или поне по-голямата част от тях, ще се погрижат така да наместват годините, че да останат верни на Паисиевия разказ. Оказва се, че не толкова историците игнорират филолозите, колкото литературата, в лицето на Паисий, диктува на историците кои са правилните факти. И затова на въпроса „В коя година е създадена славянската писменост?” учениците трябва да посочат „вярната” 855 г.

\section{Библиография}

АНГЕЛОВ, Б., ХР. КОДОВ (1973): Климент Охридски. Събрани съчинения. Том трети, Изд. БАН, София.

БИЛЬБАСОВ, В. (1871): Кирилл и Мефодий, II, Санкт Петербург.

БОДЯНСКИЙ, О (1855): О времени происхождения славянских писмен, Москва. 
БУРМОВ, А. (1951-52): „За началото на славянската писменост и книжнина”, Исторически преглед, 1.

БУРМОВ, Т. (1859-60): „За началото, разпространението и утвърждението на християнската вяра между българите”, Български книжищи, 1859, ч. 2, 575-582, ч. 3, 600$611,743-755,812-819 ; 1860$, ч. 1, 10-13.

ГЕОРГИЕВ, Е. (1980): Люлка на старата и новата българска писменост, Народна просвета, София.

ГИЛЬФЕРДИНГ, А. (1862): Собрание съчинения, T.1, Санкт Петербург.

ДИНЕКОВ, П., К. КУЕВ, Д. ПЕТКАНОВА (1967): Христоматия по старобългарска литература. Второ подобрено издание, София.

ДИМИТРОВ, Б. 2005: 12 мита в българската история, София.

ДРИНОВ, М (1869): Исторически преглед на българската изъква от самото й начало до днес, Виена.

ДОБРЕВ, И. (1977): „За александрийското и моравско-панонското летоброене и за някои дати в старата славянска писменост", Годишник на СУ. Факултет по славянски филологии, № 69, 121-174.

ЗЛАТАРСКИ, В. Н. (1971): История на българската държава през средните векове. Том I. История на Първото българско ияарство. Част II. От славянизацията на държавата до падането на Първото ияарство (852-1018), Наука и изкуство, София (І изд., София, 1927).

ИВАНОВА, КЛ. (1999): „Успение Методиево”, Palaeobulgarica, 23, № 4, 6-34.

ИВАНОВА, КЛ, С. НИКОЛОВА (1995): Тържество на словото, ИГ „Агата-А”, София. КУЕВ, К. (1967): Черноризеи Храбър, БАН, София.

ЛАЛЕВА, Т. (1985): „Възникване, развой и съвременно състояние на научния интерес към делото на Кирил и Методий”, Изследвания по кирилометодиевистика, Наука и изкуство, София, 5-45.

МАКАРИЙ (БУЛГАКОВ), АРХИМАНДРИТ (1846): История християнства в России до равноапостольного князя Владимира, Санкт Петербург.

МАРИНОВ, Д. (1887): История на българската литература, София.

ФИЛАРЕТ (ГУМИЛЕВСКИЙ) (1846): Еп. Кирилл и Мефодий, славянские просветите$л и$, Москва.

ХРИСТОВА, Б. (1996): Опис на ръкописите на Владислав Граматик, Велико Търново.

ЦАНЕВ, СТ. (2006): Български хроники, Изд. „Труд”, София.

ЧЕШМЕДЖИЕВ, Д. (2001): Кирил и Методий в българската историческа памет през средните векове, София.

ШАФАРИК, П. (1847): Славянские древности, Т. 2, Москва. 